УДК 9

DOI $10.21661 / \mathrm{r}-464296$

\title{
С.В. Андриайнен
}

\section{ПРОБЛЕМЫ ТЫЛОВОГО ОБЕСПЕЧЕНИЯ ВОЙСК ОТДЕЛЬНОГО КАВКАЗСКОГО КОРПУСА В НАЧАЛЕ ХІХ В.}

Аннотация: в статье на основе недавно опубликованных материалов, а также впервые введенных в научный оборот архивных материалов исследуется проблема тылового обеспечения Отдельного Кавказского корпуса. Анализируется специфика деятельности русской армии в Кавказском регионе. Изучаются основные достоинства и недостатки мероприятий А.П. Ермолова по улучшению тылового обеспечения войск Кавказского корпуса.

Ключевые слова: Северный Кавказ, Закавказье, Отдельный Кавказский корпус, Ермолов, тыловое обеспечение.

\section{S.V. Andriainen}

\section{THE PROBLEMATIC LOGISTICS SUPPORT OF THE TROOPS OF THE SEPARATE CAUCASIAN CORPS AT THE BEGINNING OF THE NINETEENTH CENTURY}

Abstract: the article investigates the problem of logistics support of the Separate Caucasian Corps on the basis of recently published materials, as well as archive data that was introduced into the scientific circulation for the first time. The specifics of the activities of the Russian army in the Caucasus region are analyzed. The main advantages and disadvantages of A.P. Ermolov's activities connected with improving the logistics of the troops of the Caucasus Corps have been studied.

Keywords: North Caucasus, Transcaucasia, Separate Caucasian Corps, Ermolov, logistics.

Деятельность генерала А.П. Ермолова в качестве командира Отдельного Грузинского (с 1820 г. - Кавказского) корпуса традиционно привлекает большое внимание исследователей. Исследователей привлекают самые разные стороны 
деятельности генерала - его политика в отношении горцев Северного Кавказа, повышение боеспособности русских войск, административные преобразования.

В рамках данной статьи мы хотим привлечь внимание к такой проблеме, как развитие системы тылового обеспечения русских войск на Северном Кавказе и в Закавказье. Данная тема относительно нечасто привлекает специальное внимание исследователей. Одним из немногих исключений является статья С.В. Гаврилова [9].

Проблема тылового обеспечения Отдельного Грузинского корпуса, т.е. снабжение войск провиантом, обмундированием, лошадьми, вооружением была одной из острейших для всех командующих корпусом, действовавших в начале XIX в.

Причиной этому были исключительного сложные природно-географические и политические условия, в которых приходилось действовать русской армии.

С 1802 г. снабжением войск на Кавказской линии и в Закавказье занималось специальное Кавказское депо. Его комиссионерства располагались в крепости Св. Димитрия (близ города Ростов на Дону) и Астрахани. Сама же комиссия находилась в Георгиевске [10, с. 141].

Доставка продовольствия для войск на Кавказе была исключительно сложным дело. Во-первых, не существовало хороших сухопутных дорог. Не случайно комиссии находились в Астрахани и Ростове, куда продовольствие можно было доставить по воде. Далее из Астрахани грузы перебрасывали по Каспийскому морю к Сладкоеричной (Шандруковской) пристани (находилась на северо-западном побережье Каспийского моря в Кизлярском уезде. Оттуда с большим трудом надо было перевозить провиант по сухопутью [10, с. 110]. Еще более сложной была доставка продовольствия в Закавказье. Военно-Грузинская дорога в то время отличалась малой пропускной способностью, а сами грузы могли быть разграблены непокорными горцами. 
Однако помимо перечисленных нами объективных причин существовали и другие. Авторы официального издания по истории Главного военно-интендантского управления было вынуждено признавать, что в царствование Александра I даже в ходе Отечественной войны 1812 г., вызвавшей большой патриотический подъем в обществе, огромный ущерб государству приносили злоупотребления провиантских чиновников, в особенности при заготовках и поставках продовольствия и обмундирования [10, с. 456-457].

Сразу после своего прибытия на Кавказ такой энергичный и опытный военачальник как А.П. Ермолов стал собирать информацию о недостатках в снабжении войск. 18 ноября 1816 г. (по старому стилю) Ермолов отправил своему другу генерал-майор А.А. Закревскому первое письмо из Тифлиса. В нем Ермолов описывал все проблемы, с которыми он столкнулся, приняв командование войсками Отдельного Грузинского корпуса.

Целый абзац в письме отводился положению дел в тыловых службах: «Провиантская часть с ума сводит. В магазинах ничего нет. Денег не присылают вовремя, присылают мало, и до сих пор почти все ассигнациями, которых здесь не берут или чрезвычайно невыгодно для казны. Скажи князю Петру Михайловичу [имеется в виду генерал от инфантерии начальник Главного штаба при Его Императорском Величестве князь П.М. Волконский - С.А.], чтобы третью часть на продовольствие непременно присылали серебром, так было представляемо и предместником моим... Теперь в таком беспорядке часть сия здесь, что все войски в Грузии местными способами довольствуются, остаются без запасов и живут от одного дня до другого» [6, с. 34].

Необходимо отметить, что письма Ермолова Закревского носили не только дружеский, но и полуофициальный характер. Закревский занимал важную должность дежурного генерала Главного штаба и письма Ермолова по сути были деловыми просьбами к нему, а не просто жалобами.

Ермолову действительно удалось добиться того, чтобы войска в Грузии продолжали получать часть причитающихся им денег серебряными монетами $[14$, c. 77$]$. 
А.П. Ермолов стал активно бороться с коррупцией и хищениями среди чиновников провиантского ведомства. Уже в 1818 г. при Моздокском гарнизонном суде слушалось дело комиссионера Шеншина, обвиненного в поставках продовольствия для Мингрельского егерского полка по завышенным ценам [1]. В том же году в крепости Св. Димитрия был предан суду комиссионер 8 класса Домонтович [2].

Продолжалась борьба и в последующие годы. В 1823 г. был предан суду сам управляющий Астраханским провиантским комиссионерством Каменский и комиссионер Зотов [3]. В 1825 г. при Георгиевском гарнизонном батальоне состоялся суд над комиссионером 9 класса Корчевским по обвинению его в грубости в отношении начальства [5].

Помимо чиновников, имевших классные чины, суду предавались и служители низших рангов. А.П. Ермолов обоснованно считал, что дисциплина и единство требований должны применяться ко всем служителям.

В 1825 г. при Севастопольском пехотном полку был осужден провиантский вахтер Степан Мулин, обвиненный в растрате казенного провианта. Несмотря на невысокое звание, вахтер, по версии следствия. Сумел украсть продовольствия на сумму в 3848 р. асс [4].

Новая система стала приносить свои результаты. Уже в феврале 1817 г. Ермолов в очередном письме Закревскому с удовлетворением сообщал, что он сумел добиться улучшения продовольственного снабжения войск.

В том же письме Ермолов описал свой проект переноса комиссариатской комиссии из крепости Св. Дмитрия в Ставрополь. По его словам, «в крепости Св. Димитрия комиссариат довольствует весь Грузинский корпус и сверх того одни только войска в Крыму стоящие, которых весьма немного; их можно обратить в какое-нибудь другое депо... Казне стоит чрезвычайно дорого перевозка амуниции в Грузию, а когда будет комиссариат в Ставрополе, начальник войск на линии и губернатор, оба подчиненные мне, доставят ее и дешевле гораздо и всегда в удобнейшее время» [6, с. 55]. 
Поскольку рассмотрение в Военном министерстве предложений Ермолова затягивалось, то в своих письмах он продолжал жаловаться Закревскому на печальное положение дел. В письме от 27 июня 1819 г. он просил А.А. Закревского похлопотать о его проекте разделить провиантское управление на две части Грузинскую и Кавказскую. По словам Ермолова, существование единого ведомства было абсурдным: «Каждый день испытываю я неудобства теперешнего управления, и кто не согласится со мною, что таково оно должно быть, когда из Тифлиса должно управлять действиями комиссионеров, производящих главнейшие закупки в Воронеже и Саратове. Каждая малейшая перемена, всякое ничтожное приказание не иначе последовать может как из Тифлиса» [6, с. 186].

Исполнение этого проекта Ермолова затянулось до 1821 г. В указанном году система провиантских магазинов, которые снабжали Отдельный Кавказский корпус была реорганизована. В Тифлисе и Георгиевске (с 1823 г. в Ставрополе) были учреждены отдельные комиссионерства, занимавшиеся поставкой продовольствия.

В местах квартирного расположения полков были учреждены продовольственные магазины, которые находились в полном ведении полков [7, с. 8].

Отдельной большой проблемой была доставка заготовленного продовольствия войскам на Кавказскую линию и в Закавказье. В 1819 г. Ермолов с досадой писал Закревскому: «В прошлом году, как тебе известно, замерз мой провиант при устьях Волги; теперь, по удивительной деятельности астраханского губернатора, провианта у меня множество, но от пристани развозить нечем. На линии скотский падеж ужаснейший, и нагайцы, которых я сам пригласил к перевозке... перевесть не в состоянии... От сего может не состояться мой поход в Дагестан...» [6, с. 192-193].

А.П. Ермолов активно занимался улучшением коммуникаций. Первостепенное внимание уделялось развитию Военно-Грузинской дороги.

Еще в марте 1816 г., когда Грузинским корпусом командовал генерал от инфантерии Н.Ф. Ртищев для содержания дороги в исправном была создана особая 
пионерная рота. В 1819 г. по инициативе Ермолова для перевозки воинских грузов было создано специальное военно-транспортное соединение - «воловий и конный транспорт» [9, с. 22].

Подводя итоги, мы должны признать высокую эффективность деятельности генерала А.П. Ермолова. Генералу удалось наладить достаточно эффективное снабжение воинских частей вверенного ему корпуса. Немаловажным был и финансовый аспект. Российская империя на протяжении 1810-х-1820-х гг. испытывала острые финансовые проблемы. Благодаря деятельности Ермолова к 1825 г. стоимость суточного довольствия одного нижнего чина снизилась на $30 \%$, а одной строевой лошади на $50 \%$ [9, с. 23].

Ермолов даже сумел сэкономить внушительную сумму в 1,5 млн. руб. выделенных на продовольствие корпуса [16, с. 360].

В то же время даже такой энергичный главнокомандующий как Алексей Петрович Ермолов не мог в корне исправить все проблемы. Слабым местом русской армии продолжали оставаться коммуникации. Даже в 1834 г. важнейшая Сладкоеречная пристань оставалась слабо оборудованной. По словам современника «Сладкоеричная... пристань... есть только складочное место для большого количества провианта... Здесь нет ни гавани, ни рейда. Даже пристань представляет некоторые неудобства» [8, с. 105].

Не удалось полностью преодолеть и проблему злоупотреблений. Более того, подчинение продовольственных магазинов полковым командирам и активное развитие полковых хозяйств открывало широкое поле для незаконной деятельности нечистоплотных армейских офицеров [7, с. 8].

Преодоление всех указанных проблем было возможным только после комплексного преобразования всей экономики и социального строя Российской империи в ходе Великих реформ Александра II.

\section{Список литературы}

1. Российский государственный военно-исторический архив. Ф. 801 Оп. 108 Ч. 1 Д. 1. Военно-судное дело комиссионера 9 класса Шеншина. 
2. Российский государственный военно-исторический архив. Ф. 801 Оп. 108 Ч. 1 Д. 16. Военно-судное и следственное дело над комиссионером 8 класса Домонтовичем.

3. Российский государственный военно-исторический архив. Ф. 801 Оп. 108 Ч. 5 Д. 5 Военно-судное дело об управляющем Астраханским провиантским комиссионерством 8 класса Каменским и 9 класса Зотовым.

4. Российский государственный военно-исторический архив. Ф. 801 Оп. 108 Ч. 7 Д. 7 Военно-судное дело провиантского вахтера Степана Мулина.

5. Российский государственный военно-исторический архив. Ф. 801 Оп. 108 Ч. 7 Д. 9. Военно-судное дело комиссионера 9 класса Корчевского.

6. Ермолов А.П. Кавказские письма. - СПб., 2014.

7. Бобровский П.О. История 13-го Лейб-Гренадерского Эриванского Его Величества полка за 250 лет: В 5 ч. Ч. 4. - 1895.

8. Каспийская торговля // Библиотека для чтения. - 1834. - Т. 7. - С. 85-110.

9. Гаврилов С.В. Отдельный Кавказский корпус в первой половине XIX века: особенности материального снабжения // Известия Российского государственного педагогического университета имени А.И. Герцена. - СПб., 2009. №97. - C. 21-28.

10. Главное интендантское управление. Исторический очерк / Столетие военного министерства. 1802-1902: В 50 т. Т. V. Ч. 1.

11. Гордин Я.А. Ермолов. - М.: Молодая гвардия, 2012.

12. Клычников Ю.Ю. Деятельность А.П. Ермолова на Северном Кавказе: Автореф. дис. ... канд. ист. наук. - Армавир. 1998.

13. Лапин В.В. Русская армия в Кавказской войне. - СПб., 2008.

14. Муравьева Л.А. Финансово-экономические ведомства России в первой половине XIX века // Финансы и кредит. - М., 2011. - №21. - С. 71-80. 
15. Нечитайлов М.В. Военно-бытовая повседневность солдат и офицеров Кавказского корпуса (1817-1864): материальный аспект. Дис. ... канд. ист. наук. - М., 2005.

16. Погодин М.П. Алексей Петрович Ермолов. Материалы для биографии. СПб., 1864.

Андриайнен Станислав Вальтерович - канд. ист. наук, доцент ФГБОУ ВО «Санкт-Петербургский государственный экономический университет», Россия, Санкт-Петербург.

Andriainen Stanislav Valterovich - candidate of historical sciences, associate professor at FSBEI of HE "Saint Petersburg State University of Economics", Russia, Saint-Petersburg. 